Rowatt, E. (1955). J. gen. Microbiol. 13, 552-560

\title{
Amino Acid Metabolism in the Genus Bordetella
}

\author{
BY ELIZABETH ROWATT
}

Lister Institute of Preventive Medicine, Elstree, Hertfordshire

\begin{abstract}
SUMMARY: Bordetella pertussis, B. parapertussis and B. bronchiseptica all grow in an amino acid medium, using glutamate and forming ammonia from it. After the glutamate has been used, $B$. pertussis and $B$. parapertussis deaminate aspartic acid, serine, glycine, alanine and proline. B. bronchiseptica, as well as these amino acids, deaminates threonine, valine, methionine, the leucines and phenylalanine, leaving only histidine, lysine and arginine. B. bronchiseptica grows the most rapidly of the three and $B$. pertussis the most slowly. All three organisms oxidize glutamate to give $\mathrm{CO}_{2}$ and ammonia but in each some nitrogen is unaccounted for. $B$. bronchiseptica contains a glutamic decarboxylase and $B$. parapertussis forms a pink pigment from tyrosine.
\end{abstract}

The genus Haemophilus originally contained organisms which required blood for growth. As the true requirements of the species were found, it became clear that blood was required by different members for different reasons. The influenzae-parainfluenzae-canis group needs haemin and coenzyme $\mathbf{I}$, but $H$. pertussis grows in the absence of both these compounds (Fildes, 1923). The precise function of blood in the growth of $H$. pertussis is not yet known. $H$. parapertussis and $H$. bronchisepticus, although they do not need blood for growth, resemble $\boldsymbol{H}$. pertussis and differ from the $\boldsymbol{H}$. influenzae group in not using carbohydrates (see Topley \& Wilson's Principles, 1946; Jebb \& Tomlinson, 1951) and the three species are also antigenically related (Ferry \& Noble, 1918; Bradford \& Slavin, 1937). López (1952) has suggested that $H$. pertussis, $\boldsymbol{H}$. parapertussis and $\boldsymbol{H}$. bronchisepticus should be put together in a new genus, Bordetella. Proom (1955) showed that the growth requirements of the three species are similar, but the metabolism has not yet been adequately investigated. It was to compare the amino acid metabolism of these species that the present work was undertaken.

\section{METHODS}

Organisms. Virulent strains of Bordetella pertussis were obtained from several public health laboratories and dried by the method of Greaves (1944) at the third subculture after isolation. They were maintained on Bordet Gengou medium (BG) and discarded at the 14th subculture, when another dried culture was opened. The strains of B. parapertussis C 803, C 691, NCTC 8250 NCTC 7385 and $B$. bronchiseptica NCTC 8752, 8760, 8762 were maintained on digest agar (DA). All cultures were incubated at $35^{\circ}$.

Growth experiments. Growth experiments were carried out in a liquid medium similar to that of Cohen \& Wheeler (1946) except that cysteine and 
yeast extract were sterilized by filtration and added to the medium after it had been autoclaved (C.W. 1). Yeast extract was made by extracting dried yeast (Standard Yeast Co.) for $15 \mathrm{~min}$. with an equal weight of water at $100^{\circ}$ and used at a concentration of 1 in 400. The amino acid source was Difco vitamin-free Casamino acids containing $36 \%$ amino acid (dry weight). The $\mathrm{pH}$ value of C.W. 1 medium after autoclaving was 6.9-7.0. Inocula of Bordetella pertussis were grown for 24 or $48 \mathrm{hr}$. on BG plates and inocula of the other organisms on DA medium. The cells were suspended in phosphate saline ( $\mathrm{pH} 7$ ) and $0.02 \mathrm{ml}$. added to each $20 \mathrm{ml}$. C.W. 1 medium to give a final concentration of about $10^{-7} \mathrm{mg}$. dry weight $/ \mathrm{ml}$., or $10^{3}$ viable cells $/ \mathrm{ml}$. The medium was contained in $100 \mathrm{ml}$. Erlenmeyer flasks capped with $30 \mathrm{ml}$. beakers and incubated on a horizontal shaker (Kantorowicz, 1951). Flasks were removed at intervals and stored at $4^{\circ}$. With cultures of $B$. bronchiseptica, samples were removed for turbidity estimation and the rest of the culture heated at $65^{\circ}$ for $15 \mathrm{~min}$. to inactivate glutamic decarboxylase.

Washed suspensions. Organisms were grown in $250 \mathrm{ml}$. quantities of C.W. 1 medium contained in penicillin flasks. Bordetella pertussis was grown for $48 \mathrm{hr}$. and $B$. bronchiseptica for $24 \mathrm{hr}$. from an inoculum of about $0.1 \mathrm{mg}$. dry wt. organisms $/ 250 \mathrm{ml}$. With this size of inoculum, growth of $\boldsymbol{B}$. parapertussis was poor after $24 \mathrm{hr}$. and, after $40 \mathrm{hr}$. incubation, oxygen uptake was slow; cultures grown for $24 \mathrm{hr}$. from an inoculum of $1 \mathrm{mg}$. dry wt./250 ml. were therefore used. The organisms were spun from the medium, washed in phosphate saline (pH 7) and resuspended in an appropriate buffer.

Oxidation of glutamate. Washed suspensions of organisms were incubated at $37^{\circ}$ in Warburg manometer flasks of about $20 \mathrm{ml}$. capacity having one or two side arms. The suspension (3-7 mg. dry wt.) was put in the side arm and glutamate (final concentration $0.0087 \mathrm{M}$ ) in the main compartment, each being made up in $0.11 \mathrm{M}$-phosphate buffer to give a final volume of $2.3 \mathrm{ml}$. $\mathrm{CO}_{2}$ output and $\mathrm{O}_{2}$ uptake were measured by the method of Warburg \& Yabusoe (1924). Oxygen uptake was estimated in four cups and, when the reaction was virtually over, the contents of these were pooled, heated at $65^{\circ}$ for $15 \mathrm{~min}$. and stored at $4^{\circ}$ until ammonia and glutamate estimations and amino acid chromatograms were carried out. Rates of reaction were expressed as $Q_{\mathrm{o}_{2}}\left(\mu \mathrm{l} . \mathrm{O}_{2} \mathrm{used} / \mathrm{mg}\right.$. dry wt. organisms/hr.).

Decarboxylation of glutamate. Washed suspensions (2-6 mg. dry wt. in $3.5 \mathrm{ml}$.) were incubated in manometer flasks with $0.2 \mathrm{M}$-acetate buffer containing $0.0057 \mathrm{M}$-glutamate and $0.09 \%(\mathrm{w} / \mathrm{v})$ cetavlon. $\mathrm{CO}_{2}$ output was measured directly in air at $37^{\circ}$.

Viable counts were made by the method of Miles \& Misra (1938) using BG plates for all organisms.

Concentration of suspensions of organisms was measured by a Gambrell photoelectric colorimeter with a minus red filter. The dry weight was related to turbidity by means of an empirical calibration curve. A suspension containing $\mathbf{0 . 2 0} \mathrm{mg}$. dry wt./ml. had the same turbidity as the American N.I.H. Haemophilus pertussis vaccine standard of $10,000 \times 10^{6}$ organisms $/ \mathrm{ml}$. Nitrogen estimation by micro-Kjeldahl gave $12 \%$ nitrogen for each species. 
Ammonia was estimated with boric acid in Conway units according to Hawk, Oser \& Summerson (1949).

Glutamic acid estimation. Glutamate was estimated with the decarboxylase of Clostridium reelchii S.R.12 using $0 \cdot 09 \%$ cetavlon in $0.2 \mathrm{M}$-acetate buffer pH 4.9 (see Krebs, 1948).

Paper chromatographs. Culture $(0.01 \mathrm{ml}$.) was applied to Whatman no. I paper, and one-way chromatograms were run overnight using $n$-butanol+ acetic acid + water in the proportion of $5: 1 \cdot 2: 5$ and sprayed with $0 \cdot 1 \%$ ninhydrin in $90 \%$ butanol containing $0.1 \%$ collidine (see Woiwod, 1949).

\section{RESULTS}

Metabolism during growth

Rate of growth in liquid medium. The C.W. 1 medium was used for these experiments because Bordetella pertussis requires an inoculum equivalent to c. $10^{-4} \mathrm{mg}$. dry wt. organisms $/ \mathrm{ml}$. for consistent growth in the original Cohen \& Wheeler medium containing autoclaved cysteine, and, with such a large inoculum, it is difficult to obtain satisfactory replicates. When the cysteine is sterilized by filtration, organisms equivalent to $10^{-7} \mathrm{mg}$. dry wt./ml. are an adequate inoculum. Growth experiments were carried out with three strains each of $\boldsymbol{B}$. pertussis, parapertussis and bronchiseptica. The results obtained within a species were consistent; a representative experiment is recorded in Fig. 1 and Tables 1 and 2. B. bronchiseptica grew most quickly, having the

Table 1. Rate of growth of Bordetella pertussis, B. parapertussis and B. bronchiseptica Cultures grown in $20 \mathrm{ml}$. C.W. 1 medium at $35^{\circ}$.

$\begin{array}{cccc} & \text { Lag phase } & \text { Primary M.G.T. } & \text { Secondary M.G.T. } \\ \text { Organism and strain no. } & \text { (hr.) } & \text { (hr.) } & \text { (hr.) } \\ \text { B. pertussis M 2400 } & 9 & 2 \cdot 8 & 10 \\ \text { B. parapertussis C 691 } & 9 & 1 \cdot 7 & \mathbf{3 \cdot 3} \\ \text { B. bronchiseptica } 8752 & 4 & 1 & \text { c. } 20\end{array}$

shortest lag phase and mean generation time (M.G.T.) in the log phase (Table 1). It grew at a constant rate until the maximum turbidity was almost reached and then the rate decreased progressively (Fig. 1). B. parapertussis grew at a constant rate for about $20 \mathrm{hr}$. and then at half this rate (Table 1) for about $4 \frac{1}{2}$ generations (a 20 -fold increase in dry weight) before growth finally stopped. B. pertussis, which grew the most slowly, also had a second slower logarithmic growth rate a quarter of the primary M.G.T. but it lasted for only $2 \frac{1}{2}$ generations or a six-fold increase in dry weight. The increase in turbidity with the last two organisms followed the same course as the viable count during the secondary growth phase but, in B. bronchiseptica, the turbidity increased sevenfold with a falling M.G.T. after the end of the logarithmic phase as determined by viable count. During the same period (24-31 hr.) the viable count only increased $2 \frac{1}{2}$ times (Fig. 1 and Table 2). 
Table 2. Glutamate and amino acid metabolism during growth of Bordetella spp.

Cultures incubated at $35^{\circ}$ on shaker in Cohen \& Wheeler medium containing 110-120 $\mu \mathrm{l}$. glutamate $/ \mathrm{ml}$.

\begin{tabular}{|c|c|c|c|c|c|}
\hline Organism & $\begin{array}{l}\text { Time } \\
\text { (hr.) }\end{array}$ & $\begin{array}{l}\text { Turbidity } \\
\text { (mg./ml.) }\end{array}$ & $\begin{array}{c}\text { Glutamate } \\
\text { used } \\
(\mu \mathrm{l} . / \mathrm{ml} .)\end{array}$ & $\begin{array}{l}\text { Ammonia } \\
\text { formed } \\
(\mu l . / \mathrm{ml} .)\end{array}$ & Chromatogram showed \\
\hline B. pertussis M 2400 & $\mathbf{5 5}$ & $0 \cdot 015$ & $\mathbf{1}$ & 2 & . \\
\hline \multirow[t]{4}{*}{ Subculture 9} & 64 & $0 \cdot 090$ & 7 & 13 & . \\
\hline & 72 & $0 \cdot 23$ & 53 & 51 & Glutamate lighter \\
\hline & 79 & $0 \cdot 38$ & 111 & 110 & Glutamate gone \\
\hline & 88 & 0.55 & 110 & 214 & $\begin{array}{l}\text { Glycine, serine, aspartic acid, } \\
\text { alanine, proline lighter }\end{array}$ \\
\hline \multirow[t]{6}{*}{ B. parapertussis C 691} & 40 & 0.02 & 8 & 9 & . \\
\hline & 44 & 0.05 & 21 & 22 & . \\
\hline & 48 & $0 \cdot 12$ & 54 & 38 & Glutamate lighter \\
\hline & 55 & 0.50 & 112 & 89 & Glutamate gone \\
\hline & 64 & 0.90 & 112 & 203 & $\begin{array}{l}\text { Glycine, serine, aspartic acid, } \\
\text { alanine lighter, proline gone }\end{array}$ \\
\hline & 72 & 0.95 & - & 262 & $\begin{array}{l}\text { Glycine, serine, aspartic acid, } \\
\text { alanine lighter, proline gone. } \\
\text { New spot above valine }\end{array}$ \\
\hline \multirow[t]{7}{*}{ B. bronchiseptica 8752} & 20 & $0 \cdot 015$ & 10 & 9 & . \\
\hline & 24 & $0 \cdot 11$ & 15 & 15 & . \\
\hline & $27 \frac{1}{2}$ & $0 \cdot 35$ & 50 & 49 & . \\
\hline & 31 & 0.80 & 74 & 67 & . \\
\hline & $\mathbf{3 5}$ & 0.95 & 112 & 111 & Glutamate gone \\
\hline & 44 & $1 \cdot 20$ & 117 & 205 & Glutamate gone, leucine less \\
\hline & $51 \frac{1}{2}$ & $1 \cdot 30$ & - & 274 & All but basics and valine lighter \\
\hline
\end{tabular}

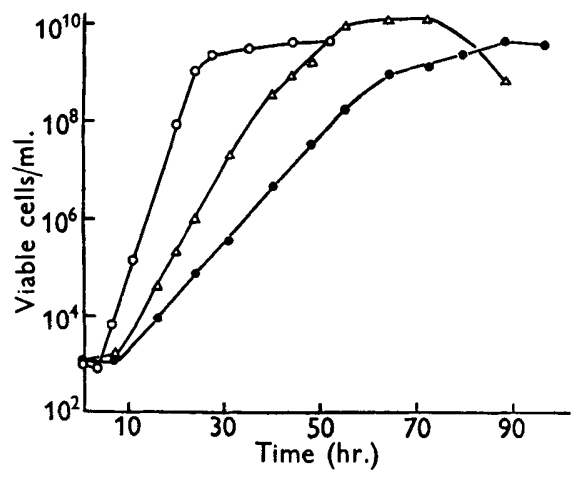

Fig. 1

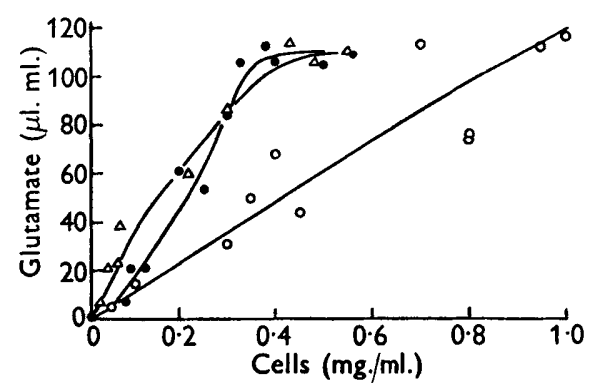

Fig. 2

Fig. 1. Rate of growth of Bordetella bronchiseptica, B. parapertussis and B. pertussis. Cultures grown in $20 \mathrm{ml}$. C.W. 1 medium at $35^{\circ}$. Results from same experiments as shown in Tables 1 and 2 . B. pertussis, $\quad B$. parapertussis, $\triangle-\triangle$; B. bronchiseptica, $\bigcirc-\mathrm{O}$.

Fig. 2. Relation of growth of Bordetella spp. to glutamate utilization. Cultures grown in $20 \mathrm{ml}$. C.W. 1 medium at $\mathbf{3 5}^{\circ}$. Results from three strains of each species. B. pertussis, $\longrightarrow$ - B. parapertussis, $\triangle \longrightarrow \triangle ; B$. bronchiseptica, $\bigcirc \longrightarrow \bigcirc$. 
Metabolism of glutamate during growth. In Cohen \& Wheeler medium each species used glutamate for growth before other amino acids (see Jebb \& Tomlinson, 1951). The growth rate of all three species fell when only about $10 \%$ of the total glutamate had been used and the $\mathrm{pH}$ value of the medium had risen from $\mathrm{pH} \mathrm{7 \cdot 0} \mathrm{to} \mathrm{about} \mathrm{7 \cdot 3.} \mathrm{Growth} \mathrm{of} \mathrm{Bordetella} \mathrm{parapertussis,} \mathrm{but} \mathrm{not}$ of the other two organisms, continued at a steady rate for a short time after the rate of glutamate utilization had slowed down. The weight of cell substance formed by $\boldsymbol{B}$. bronchiseptica for a given quantity of glutamate was greater than that formed by the other two organisms (Fig. 2). The ratio of ammonia formed to amount of organisms with $\boldsymbol{B}$. parapertussis, however, resembled that with $\boldsymbol{B}$. bronchiseptica. B. pertussis and $\boldsymbol{B}$. bronchiseptica usually produced quantities of ammonia equivalent to the glutamate used (Table 2), but in a few experiments $B$. bronchiseptica formed slightly more ammonia than was accounted for by the glutamate disappearing. B. parapertussis formed slightly less than the expected quantity of ammonia.

Metabolism of other amino acids. After the glutamate had been used, ammonia formation continued at a decreased rate at the expense of other amino acids. Bordetella pertussis and B. parapertussis formed $c .300 \mu \mathrm{l}$. ammonia $/ \mathrm{ml}$. and aspartic acid, serine, glycine, glutamate, alanine and proline disappeared from the chromatogram (Table 2). Other amino acids were not used to an extent detectable on paper chromatograms. B. bronchiseptica deaminated the same amino acids and leucine, and finally only the basic amino acids were left, up to $400 \mu \mathrm{l}$. ammonia being formed. The only new nitrogen-containing compound showing up on the chromatograms was a spot above valine and methionine in the later stages of growth of $B$. parapertussis. It may have something to do with the brown pigment formed from tyrosine by this organism (see below) which only appears when growth is almost over.

It should be noted that in the key of amino acid positions on a chromatogram run in butanol + acetic acid given by Proom \& Woiwod (1949), the amino acid in the crescent-shaped spot between the basic amino acids and glycine and serine (position $\mathrm{C}$ ) is stated to be aspartic acid. However, when aspartic acid is run in a culture fluid of the kind used here it occupies the same position as glycine and serine; the amino acid which gives the crescent-shaped spot is arginine. When arginine is run in a salt solution such as phosphate buffer or a culture fluid it is concentrated into a very narrow line and has a slightly lower $\boldsymbol{R}_{\boldsymbol{F}}$.

\section{Metabolism in washed suspensions}

Oxidation of glutamic acid by washed suspensions. Washed suspensions of the three species oxidized glutamate with formation of ammonia (see Jebb \& Tomlinson, 1951). The highest $\boldsymbol{Q}_{\mathrm{O}_{2}}$ found for Bordetella pertussis and $\boldsymbol{B}$. parapertussis was $100 ; B$. bronchiseptica had a $Q_{\mathrm{O}_{2}}$ of up to 130 . With each species the $Q_{\mathbf{O}_{\mathbf{2}}}$ fell with increasing age of organisms. This was most noticeable with B. parapertussis which had a $Q_{\mathrm{o}_{\mathrm{g}}}$ of, for example, 84 after $29 \mathrm{hr}$. growth and of 16 after $48 \mathrm{hr}$. growth. The relative quantities of ammonia and $\mathrm{CO}_{2}$ formed and of oxygen and glutamate used are shown in Table 3. With each species, 
the ammonia formed was less than the quantity of glutamate used. Nitrogencontaining compounds were not apparent on chromatograms of suspensions of $\boldsymbol{B}$. pertussis and $\boldsymbol{B}$. bronchiseptica, but with $\boldsymbol{B}$. parapertussis two compounds were present in the positions occupied by ornithine and arginine. These compounds were also found after metabolism of glutamate by two atypical strains of phase IV B. pertussis, G 154 E and G 146 E (Baddiley, Rowatt \& Standfast, 1952). The ornithine-like compound was purified on columns of Amberlite IR 120 and IRA 400 and characterized as the dibenzoyl derivative. The melting point was the same as that of authentic ornithuric acid. The second spot had the same $R_{F}$ as arginine when run in butanol + acetic acid and in phenol $+\mathrm{NH}_{3}$, gave ornithine when heated at alkaline $\mathrm{pH}$ and was decarboxylated by the specific arginine decarboxylase of Escherichia coli 7020 (Gale, 1946) and consequently almost certainly was arginine. The quantity of these compounds was not estimated; it is not possible to say whether they account for all the missing nitrogen.

Table 3. Glutamate metabolism by washed suspensions of Bordetella spp.

Suspensions incubated in $0.11 \mathrm{~m}$-phosphate buffer (pH 7 ) with $0.0087 \mathrm{~m}$-glutamate at $37^{\circ}$ in air.

Organism and strain no.

B. pertussis W 2043

B. parapertussis C 803

B. bronchiseptica $\mathbf{8 7 6 0}$

$\begin{array}{cc}\begin{array}{c}\text { mole } \mathrm{NH}_{3} / \\ \text { mole } \\ \text { glutamate }\end{array} & \begin{array}{c}\text { atoms } \mathrm{O} / \\ \text { mole } \\ \text { glutamate }\end{array} \\ 0.76 & \mathbf{5 . 3} \\ 0.54 & 4.7 \\ 0.62 & 4.8\end{array}$

$4 \cdot 8$

$\begin{array}{cc}\begin{array}{c}\text { mole } \mathrm{CO}_{2} / \\ \text { mole }\end{array} & \begin{array}{c}\text { atoms } \mathrm{O} / \\ \text { mole }\end{array} \\ \text { glutamate } & \mathrm{CO}_{2} \\ \mathbf{3 \cdot 2} & 1 \cdot 60 \\ 2 \cdot 9 & 1 \cdot 65 \\ 3 \cdot 1 & 1.5\end{array}$

Glutamic decarboxylase. Washed suspensions of Bordetella bronchiseptica when incubated with glutamate at $\mathrm{pH} 4.9$ formed $\mathrm{CO}_{2}$ and an amino compound which had the same $\boldsymbol{R}_{\boldsymbol{F}}$ value as authentic $\gamma$-aminobutyric acid in butanol + acetic acid + water $(5: 1 \cdot 2: 5$ and $8: 1: 10)$ and in butanol + water. The $R_{F}$ of $\beta$-alanine is the same as that of $\gamma$-aminobutyric acid in the last two mixtures, but it is less in the first solvent (Synge, 1951). As with Clostridium welchii (Krebs, 1948) the rate of the reaction was increased by adding cetavlon, reaching a $\mathbf{Q}_{\mathrm{CO}_{2}}$ of 250 with some strains. Glutamic decarboxylase was not found in any strain of $B$. pertussis or $B$. parapertussis.

Urease. Strains of the three species were tested for urease activity by the method of Clarke \& Cowan (1952). B. bronchiseptica and B. parapertussis both contained the enzyme but none of the strains of $B$. pertussis did. This confirms the work of Ulrich \& Needham (1953) on B. bronchiseptica and of López (1952) on all three species.

Formation of pigment from tyrosine. Bradford \& Slavin (1937) showed that Bordetella parapertussis, unlike $B$. pertussis, formed a brown pigment during growth. Ensminger (1953) found that tyrosine was necessary for the formation of this pigment. Washed suspensions of $\boldsymbol{B}$. parapertussis incubated with tyrosine formed a pink pigment which turned brown on prolonged incubation. 
Glutamate increased pigment formation and the reaction was more rapid at pH $7 \cdot 4$ than at the lower $\mathrm{pH}$ values (Table 4). Three strains of $B$. pertussis and one of $B$. bronchiseptica incubated in this way did not form any pigment, nor was any formed during growth of either species.

\section{Table 4. Formation of pigment from tyrosine by washed suspensions of Bordetella parapertussis}

B. parapertussis 7385 equivalent to $0.95 \mathrm{mg}$. dry wt./ml. in $10 \mathrm{ml} .0 .08 \mathrm{M}$-phosphate buffer at various $\mathrm{pH}$ values. Incubated $34 \mathrm{hr}$. at $37^{\circ}$. Colour measured as percentage absorption on Gambrell photoelectric colorimeter, with blue-green filter.

\begin{tabular}{|c|c|c|c|}
\hline & \multicolumn{3}{|c|}{$\mathrm{pH}$ value of suspensions } \\
\hline & 6.4 & $7 \cdot 0$ & $7 \cdot 4$ \\
\hline & \multicolumn{3}{|c|}{ Colorimeter reading } \\
\hline Substrate & & & \\
\hline None & $13 \cdot 5$ & $15 \cdot 5$ & 16 \\
\hline 0.01 M-glutamate & 15 & 18 & $21 \cdot 5$ \\
\hline 0.0011 M-tyrosine & $14 \cdot 5$ & 16 & 22 \\
\hline $\left.\begin{array}{l}0.01 \text { m-glutamate } \\
0.0011 \text { m-tyrosine }\end{array}\right\}$ & 17 & $31 \cdot 5$ & $60 \cdot 5$ \\
\hline
\end{tabular}

\section{DISCUSSION}

It has been shown that Bordetella pertussis, B. parapertussis and B. bronchiseptica use glutamate for growth in preference to the other amino acids in casein hydrolysate. Some growth takes place on these amino acids but, since the growth rate falls when only a tenth of the glutamate has been used, growth at this stage must be limited by factors other than the glutamate concentration. We have not tested logarithmic growth on a medium deficient in glutamate, but Jebb \& Tomlinson (1951) obtained poor growth in a medium without added glutamate even with so large an inoculum as $10^{7}$ organisms $/ \mathrm{ml}$. Proom (1955) reported growth of $B$. pertussis in a medium without added glutamate, but gave no details of size of inocula or of amount of growth.

With each species tested here the growth rate fell when about $10 \%$ of glutamate had been used. The shape of the growth curves suggests that the medium is adequate for Bordetella bronchiseptica; that after some growth of $B$. parapertussis, a factor (or factors) is used up and growth is able to continue at a slower rate; and after some factor, possibly the same one, has been exhausted by $\boldsymbol{B}$. pertussis, growth is poor and stops before a dry weight of organisms as large as with the other two organisms is reached.

The only amino acids not used by $\boldsymbol{B}$. bronchiseptica are the basic amino acids. The high $\mathrm{pH}$ value obtaining at the end of growth (about $8 \cdot 4$ ) may prevent the metabolism of these amino acids. It is noteworthy that this organism contains a glutamic decarboxylase which acts at an acid $\mathrm{pH}$ value. $\gamma$-Amino butyric acid, the product of decarboxylation, is not present after oxidation of glutamate, nor, in any quantity, after growth.

The organisms use more glutamate for growth than any other compound and it is generally assumed that this substance is the energy source. In the 
medium used in these studies it cannot be the source of nitrogen for growth, because the quantity of nitrogen in the glutamate used and in the cells is of the same order of magnitude and the glutamate nitrogen appears as ammonia. During the later stage of growth of Bordetella parapertussis, some glutamate nitrogen does not appear as ammonia but this is not enough to account for the increase in cell nitrogen. It might be used to form arginine and ornithine, a reaction occurring in washed suspensions of this organism. Ammonia of the medium is not used up and no single amino acid is used in any quantity until after the glutamate of the medium has been exhausted. The cell nitrogen must, therefore, come from small quantities of many amino acids in the medium. It cannot yet be said whether these are degraded before incorporation or whether they are built into the cell protein unaltered.

Properties of the three species are summarized in Table 5.

Table 5. Comparison of metabolism of Bordetella pertussis, B. parapertussis and $\mathrm{B}$. bronchiseptica

\begin{tabular}{|c|c|c|c|c|c|c|c|c|}
\hline Organism & $\begin{array}{c}\text { Mean } \\
\text { generation } \\
\text { time } \\
\text { (hr.) }\end{array}$ & $\begin{array}{l}\text { Main amino } \\
\text { acid used }\end{array}$ & $\begin{array}{l}\mathrm{NH}_{3} / \\
\text { Glutamate } \\
\text { ratio in } \\
\text { growth } \\
\text { (moles) }\end{array}$ & $\begin{array}{l}\text { Amino acids } \\
\text { deaminated } \\
\text { in growth } \\
\text { on casein } \\
\text { hydrolysate }\end{array}$ & $\begin{array}{l}\mathrm{NH}_{3} / \\
\text { Glutamate } \\
\text { ratio in } \\
\text { washed } \\
\text { suspension }\end{array}$ & Urease & $\begin{array}{l}\text { Pigment } \\
\text { formation }\end{array}$ & $\begin{array}{c}\text { Glutamic } \\
\text { decarboxy- } \\
\text { lase }\end{array}$ \\
\hline B. pertussis M 2400 & $2 \cdot 8$ & Glutamate & 1 & $\begin{array}{l}\text { Alanine, } \\
\text { serine, } \\
\text { glycine, } \\
\text { aspartic } \\
\text { acid, proline }\end{array}$ & $0 \cdot 76$ & - & - & - \\
\hline B. parapertussis C 691 & $1 \cdot 7$ & Glutamate & $1-0 \cdot 7$ & $\begin{array}{l}\text { Alanine, } \\
\text { serine, } \\
\text { glycine, } \\
\text { aspartic } \\
\text { acid, proline, } \\
\text { sometimes } \\
\text { threonine }\end{array}$ & 0.54 & + & + & - \\
\hline B. bronchiseptica 8752 & 1 & Glutamate & 1 & $\begin{array}{l}\text { All amino } \\
\text { acids but } \\
\text { arginine, } \\
\text { lysine, } \\
\text { histidine }\end{array}$ & $0 \cdot 62$ & + & - & + \\
\hline
\end{tabular}

The author is seconded from the Central Public Health Laboratory, Colindale.

Thanks are due to Directors of Public Health Laboratories at Manchester and Cardiff for freshly isolated strains of Bordetella pertussis; to Mrs J. Sparks for skilful technical assistance and to Mr A. F. B. Standfast for helpful advice and criticism; and to Dr Elizabeth Work for the sample of $\gamma$-aminobutyric acid.

\section{REFERENCES}

Baddiley, J., Rowatt, E. \& Standfast, A. F. B. (1952). The metabolism of glutamate by some rough strains of Haemophilus pertussis. Proc. Int. Congr. Biochem. p. 75.

Bradford, W. L. \& Slavin, B. (1937). An organism resembling Haemophilus pertussis with special reference to color changes produced by its growth upon certain media. Amer. J. publ. Hlth, 27, 1277.

Clarke, P. H. \& Cowan, S. T. (1952). Biochemical methods for bacteriology. J.gen. Microbiol. 6, 187. 
Cohen, S. M. \& Wheeler, M. W. (1946). Pertussis vaccine prepared with phase-I cultures grown in fluid medium. Amer. J. publ. Hlth, 36, 371.

Ensminger, P. W. (1953). Pigment production by Haemophilus parapertussis. J. Bact. 65, 509.

Ferry, N. S. \& Noble, A. (1918). Studies relative to the apparent close relationship between Bact. pertussis and B. bronchisepticus. J. Bact. 3, 193.

Fundes, P. (1923). The classification of haemoglobinophilic bacteria, based upon their relation to blood pigment and to the 'vitamine' factor. Brit. J. exp. Path. 4, 265.

GaLe, E. F. (1946). Estimation of $\mathrm{L}(+)$-arginine in protein hydrolysates by the use of $\mathrm{L}(+)$-arginine decarboxylase. Nature, Lond. 157, 265.

Greaves, R. I. N. (1944). Centrifugal vacuum freezing. Its application to the drying of biological materials from the frozen state. Nature, Lond. 153, 485.

Hawk, P. B., Oser, B. L. \& Summerson, W. H. (1949). Practical Physiological Chemistry, 12th ed. Philadelphia: The Blakiston Co.

Jebi, W. H. H. \& Tomurnson, A. H. (1951). The catabolic activity of washed suspensions of Haemophilus pertussis. J. gen. Microbiol. 5, 951.

KaNTOROWICZ, O. (1951). Shaking apparatus for the aeration of bacterial cultures. J. gen. Microbiol. 5, 276.

KreBs, H. A. (1948). Quantitative determination of glutamine and glutamic acid. Biochem. J. 43, 51.

LóPEz, M. M. (1952). El genero Bordetella. Microbiol. esp. 5, 177.

Miles, A. A. \& Misra, S. S. (1938). The estimation of the bactericidal power of the blood. J. Hyg., Camb. 38, 732.

Proom, H. (1955). The minimal nutritional requirements of organisms of the genus Bordetella López. J. gen. Microbiol. 12, 63.

Proom, H. \& Worwod, A. J. (1949). The examination, by partition paper chromatography, of the nitrogen metabolism of bacteria. J. gen. Microbiol. 3, 319.

SYNGE, R. L. M. (1951). Methods for isolating $\omega$-amino acids: $\gamma$-aminobutyric acid from rye grass. Biochem. J. 48, 429.

Topley \& Wilson's Principles of Bacteriology and Immunology. 3rd ed. (1946). Revised by Wilson, G. S. \& Mrles, A. A. London: Edward Arnold and Co.

Ulrich, J. A. \& Needham, G. M. (1953). Differentiation of Alcaligenes faecalis from Brucella bronchisepticus by biochemical and nutritional methods. J. Bact. 65, 210.

Warburg, O. \& Yabusoe, M. (1924). Úber die Oxydation von Fructose in Phosphatlösungen. Biochem. $Z$. 146, 380.

Worwod, A. J. (1949). A technique for examining large numbers of bacterial culture filtrates by partition chromatography. J. gen. Microbiol. 3, 312. 